UDC 81 '44

DOI: $10.24044 / \mathrm{sph} .2017 .1 .12$

\title{
THE USAGE OF STYLISTIC DEVICES: METAPHOR, METONYMY, HYPERBOLE IN UZBEK AND ENGLISH HUMOROUS TEXTS
}

\author{
U. R. Yuldoshev
}

\author{
Senior scientific researcher \\ Uzbekistan State World Languages University \\ Tashkent, Uzbekistan
}

\begin{abstract}
It is known that stylistics is a branch of linguistics and it is very important aspect in creating humour. Stylistic devices of expressiveness should be investigated wider and detailed, because they created much humorous effect and used in humorous texts more. The use of the following stylistic devices is confirmed during the investigation: epithet, irony, metaphor, metonymy, personification, jargonizes, zeugma, litotes, oxymoron, amphibole, antithesis, pun, hyperbole, sarcasm, periphrases. The following stylistic devices are used more than others in humorous texts: metaphor, metonymy, hyperbole, pun, irony, personification and oxymoron. These devices are prevalent and more interesting in humour, pragmatic aspect and translation of humorous texts. Humorous texts are created on the basis of these stylistic devices of expressiveness. According to extend of research paper we tried to analyze active stylistic devices metaphor, metonymy and hyperbole used in Uzbek and English language humorous texts. We know that emotional-subjective evaluating; determining linguo-stylistic elements are one of the main problems of literary speech stylistics. This problem is very important in analyzing humorous texts, because emotional effect is considered very important aspect in this genre. Stylistic devices are used more in not only Uzbek and English nations' but also all nations' humorous texts and it is very important in creating humour. Usually the function of ridiculous is considered differential feature among stylistic devices.
\end{abstract}

Keywords: stylistic devices; Uzbek language; English language; metaphor; metonymy; hyperbole; translation; active; source language; target language.

Many researchers made research works on stylistic devices, humor, humorous texts, the role of stylistic device in causing laughter. Every scientist mentioned different view on the role of stylistic devices in causing laugher. According to Vinogradov, pun or play with homonyms have denotative and connotative meanings is one of most styles of cause laughter $[12$, p. 7]. Galperin mentioned that the most stylistic device of cause laughter is author's occasional word created by masterly combining different words by writer [3, p. 86]. Arnold considered the function of humour is specific feature of polysemy and homonymy [10, p. 103]. Chairo purposed alogism is the main style of comic [1, p. 58]. Crystal suggested whole "cascade" of stylistic devices in creating comic effect: pun, syntactic homonymy, alogism, and author's neologisms [2, p. 25].

Nash mentioned that there is more potential off humour in ambiguity, though pun explained with context or situation in which is figuring itself [5, p. 241]. Norrik guessed every stylistic 
device fill all functions, but one of others may be more dominant [6, p. 124]. By analyzing all scientists' opinions about stylistic devices which are used active in creating humorous texts we support Norrik's guess in this case. We also think that all stylistic devices are used active in cause laughter, creating humorous texts.

And now we investigate stylistic devices metaphor, metonymy, hyperbole which used active in Uzbek and English humorous texts in this research.

\section{Metaphor}

We analyze causing laughter by using stylistic device metaphor in Uzbek and English humorous texts in the follow:

Metaphor occurs by transference the name of an object to another one on the base of some quality of two objects. Metaphor means transference of some quality form one object to another [8, p. 139]. Abramovich considered metaphor is implicit type of simile [9, p. 119]. Rubaylo mentioned simile is the base of metaphor. According to Bobohonova metaphor is based on relative attitude of denotative-logical and figurative-contextual meanings [11, p. 141].

We investigate stylistic device as cause laughter in humorous texts. Transference of meaning according to an element of different animals, fowls, insects, though the use of their name to human being in metaphorical meaning and their derivative meanings in the text cause great laughter. Particular, speaker's negative attitude is reflected in metaphors have figurative meaning which cause laughter.
We analyze the Uzbek humorous text, Uzbek national folklore which is used metaphor in:

Original version: (Подшо вазири билан Афандини олиб, овга чиқди. Хийла ов қчлгандан кейин подшо устидаги чакмонини ечиб Афандига берди.

Буни куурган вазири хуам чакмонини Афандига узатди.

Подшо Афандига тегишди:

- Афанди, устингизга биз бир эшакнинг юкини ортиб куййик-а?

- Кошки эди бир эшакнинг юки бўлса, - деди Афанди. - Устимда икки эмакнинг юки бор.)

In English translation: King went hunting his vazir (this word is old fashioned version of present term minister.) and Afandi (Afandi is Uzbek national folklore character in humour.). After having hunted a little the king took off his chakmon(It is oriental robe) and gave it to Afandi.

Having seen this, vazir also passed his own chakmon Afandi.

King mocked at Afandi:

- Afandi, we loaded the luggage of a donkey, didn't we?

- I wish I had the luggage of a donkey, - said Afandi. - I have the luggage of two donkeys on my shoulders. ("Anecdotes of Afandi", Tashkent, 1983, p. 214.)

The style of witting is the base of laughter by metaphorical meaning of the word donkey and derivative meaning which was indicated by it. Here the word "donkey" is expressed with two meanings. The first one is primary meaning and the second one is derivative meaning relative with the 
word "donkey". Both of the meanings are fitted with both form and content:

1. We loaded the luggage of a donkey.

2. You are donkey, so we loaded the luggage.

1. I have the luggage of two donkeys on my shoulders.

2. I have the luggage of two bawdy, foolish people on my shoulders.

The main point caused humorous text indicative derivative meaning of the sentence "I have the luggage of two donkeys on my shoulders" based on the style witting by the second speaker (Afandi). The word "donkey" consists of semes "foolish", "bawdy", "human being" and the elements of slowness, foolishness are considered more than elements belong to human being.

Metaphors are also used active in English humorous texts.

"Excuse me," said the detective as he presented himself at the door of the music academy, "but I hope you'll give me what information you have, and not make any fuss."

"What do you mean?" was the indignant inquiry.

"Why, you see, we got a tip from the house next door that somebody was murdering Wagner, and the chief sent me down here to work on the case."

Simple metaphor was expressed with the verb "to murder" in this anecdote. Here the verb "to murder" was used in the meaning of "to play badly", "to ruin". The word "to murder" in figurative meaning said on the purpose of expressing teacher's opinion to pupil with high emotional fulfilled the metaphor. But having heard this word detective understood this word in primary meaning and thought the murdering had happened.

Derivative meaning of auxiliary construction used in metaphorical meaning cause laughter in the following humorous text:

Original version:

(Қози Афандини беда уррдиргани бовига олиб борди. Ищ тамом бўлгандан кейин зиқна қози Афандининг куйлига икки бов беда бериб:

- Мана бу-эшагингизга,-дебди. Шунда Афанди қ̧озига қ̧араб:

- Ажабо, мен эрталабдан кечгача эмак учун ишлабман - да? деб жавоб берибди.)

In English translation:

Once Qozi (old version of the name of judge in Central Asia) followed Afandi to scythe trefoil. When the work has done skimpy qozi gave two bundles of trefoil to Afandi and said:

- This is for your donkey, - said he.

Then Afandi looked at qozi and said:

- I have worked the whole day for the donkey, haven't I? - answered Afandi. ("Afandi anecdotes", Tashkent, 1989, p. 189).

The word is played with the word "donkey" in this text. The meanings of auxiliary "учун (for) in Uzbek" is formed this word play. There is also style witting in this humorous text.

It is known that the auxiliary "учун (for) in Uzbek" express meanings target, reason, naming, marking, target- 
ing by combining with the words in character of noun. We may understand both meanings in particular condition and the second one is humorous in this case. "I have worked the whole day for the donkey"- the word "donkey" is in its primary meaning, "I have worked the whole day for the donkey (human being)"- the word "donkey" is used in its second meaning "human being".

Metaphor is also used in the next English humorous text.

Mrs. Jenkins, on being shown into the doctor's consulting room, immediately started on the long story of her troubles.

The doctor, to whom she was a regular visitor, endured it patiently and gave her another bottle.

At last she prepared to go out, and the doctor was congratulating himself when she suddenly stopped and exclaimed, "Why, doctor, you didn't look to see if my tongue was coated."

"I know it isn't," wearily replied the medical man. "You don't find grass on a racetrack."

Metaphorical meaning in this text is expressed with the sentence: You don't find grass on a racetrack. Doctor is comparing his patient's language with the racetrack and patient's many sentences are compared with the grass.

\section{Metonymy}

Metonymy is also stylistic device which used active in Uzbek and English humorous texts. Use the name of an object, element, action to the name of another object, element, and action on the basis of internal and external dependence; metonymy occurred by transference the name of an object, el- ement, action to another object, element, and action on the base of such using.

Metonymy is very important in creating new meanings of a word [14, p. 54]. So, metonymy is one occurences cause to create new meaning by transference the name of every object to another object.

We review the cause laughter by transference the name on the basis of internecine dependence among objects, things in the follow.

We may see cause laughter by metonymy in Uzbek national joker Xojiboy Tojiboyev's jokes:

Original version:

Ўзбекнинг ўзи құизик.. "Хожибой ака, фалончининг ошида кўринмадиз?" - дейди. Мен гуиштманми ошда курринадиган..."

Uzbek people's words are interesting. "Xojiboy aka(Aka is a type of addressing form), you were not seen in pilov (Palov is Uzbek national dish. It is prepared in weddings in the morning, on Thursday and Sunday at home. Wedding pilav is eaten by thousands of people who came restaurant in the morning) in the morning. Am I meat which is seen in pilav..." [8, p. 113].

Metonymy is used by figurative meaning of phrases express the meaning "you were not seen in pilav-you didn't participate in ceremony" in this text. However, there is the second meaning of this sentence and it exists in case of relating to the word "pilav". Here it is not paid attention to the metonymical figurative meaning of the phrase "you were not seen in pilav". So, the phrase "were not seen in pilav" 
expresses the notion that "somebody didn't participate in ceremony or wedding" in metonymical figurative meaning and indicates communicative function of the sentence, it expresses the notion "not seen in pilav" in primary meaning and causes laughter.

Pay attention to the next humorous text in which laughter is caused by metonymy, Original version:

Халқимиз орасида яна шундай құизиқ гап бор. "Туурт киши самоварда уттириб, маза қилиб ош едик” дейитади. Самоварда-я?... Куйиб қолиш мумкинку!... Турт киши қандай сивди экан? Тугври, утириш мумкин, иунда хам фақат бир киши. Агар қзасам ичган бўлса... (Хожибой Тожибоев)

This is English version of the following text translated by word for word translation:

There is interesting sentence among Uzbek people. They say four people had pilav with enjoy sitting on the samovar (Samovar is big iron metal to boil the water. This term is also used for the place in which people come with fiends and eat only pilav in Uzbekistan. It differs from café or restaurant). How do they sit on samovar?... They may scald! How do four people sit on a samovar? It is right that human being may sit but only one person. If he took a vow...

Transference metonymic meaning created by calling the name of an object with the place of it caused laugher. In this case samovar is used a place not iron kettle according to the place in which it placed on the basis of metonymy. So, samovar means the place in the process of speech. However, speaker attracts listener's attention to the primary meaning of this phrase not figurative meaning of the phrase "to sit on samovar" by metonymy objective. As a result, one understands "to place on samovar" and cause laughter.

People use metonymy more to create humour in English humorous texts. Describing character or situation may be metonymic in examples of one of two women who lost their memory because of they are old, but the second one also cannot remember it: we see sclerosis given in the sentence "How soon do you need to know?" in which expressed by hyperbole of decreasing or vanish of memory.

One day two elderly ladies had been friends for many decades. Over the years they had shared all kinds of activities and adventures. Lately, their activities had been limited to meeting a few times a week to play cards. One day they were playing cards when one looked at the other and said, "Now don't get mad at me..... know we've been friends for a long time, but I just can't remember your name. I've thought and thought, but I can't recall it. Please tell me what your name is." Her friend glared at her. For at least three minutes she just looked at her. Finally she said, "How soon do you need to know?"

\section{Hyperbole}

Hyperbole is also used in Uzbek and English humorous texts. According to the Explanatory dictionary of Linguistic terms hyperbole means describing an object, situation, features, conditions of processes by overcharg- 
ing [14, p. 32]. Imagination created by describing an object, thing and the element related to it causes laughter in speaker or listener's imagination in humorous texts. Hyperbole means to aggrandize, to exaggerate, pursuing and there are two views of it. An object and its element is very exaggerated in the first view and is made so diminution.

The peculiar feature of hyperbole is information expressed in speech have hyperbolic image doesn't correspond to objective reality. Consequently, this correspondence causes laughter.

Hyperbole comes into existence on the basis of simile. Comparing meanings, situations, objects in simile may be imaged and simile is based on primary meanings. The element of the object is described intensified very much in hyperbole.

Writers hint at describing person's portrait and his/her character feature by hyperbolic simile in humorous texts, by this process the laugher causes.

Causing laughter by hyperbole is used in lof (It is a type of Uzbek national folklore and means overstatement, exaggeration) in Uzbek humorous texts. The word lof means incorrect, too exaggerated sentence, faithful sentence, hyperbole.

Lof is a type of Uzbek national folklore created on the basis of hyperbole and is presented as a type of satire and humour. So, it is related to askiya (It is a type of Uzbek national folklore and verbal humour of Uzbek people. It is based on witting by word play) genre from the point of its subject, com- position and the style of presenting and it is a type of epic works [11, p. 6].

In particular, lof are presented in dialogical form, speakers create humour by double hyperbolic image with the reference to an object. In this case peculiar style of witting made on the result of expressed hyperbolic meaning of the word used by the second speaker more than hyperbolic meaning of the word used by the first speaker cause laughter.

Original version:

Бир лофчи иккинчи лофчига угллини мақтади:

- Менинг уудлим уч ёш бўлишига қарамай, буйи чунонам уусиб кетдики, юлдузларни куули билан ушлаб текширяпти.

Иккинчи лофчи деди:

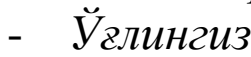
юлдузларни текшираётганда бошига бирор нарса тегмасмикан?

Биринчи лофчи булутни айтаётган буллса керак деб уй̆лади ва жавоб берди.

- Xa.

Шунда иккинчи лофчи деди:

- Ўша теккан нарса цувлим кийган туиннинг пеши бўлади.

In English translation of the original version:

A lof-maker boasted of his son to another lof-maker.

- Although my son is three years old he is very tall and he is checking the stars catching with his hands.

The second lof-maker said:

- When your son is checking the stars does something touch your son?

The first lof-maker thought he is speaking about clouds and said: 
- Yes.

Then the second lof-maker said:

The touched thing is the lower part of my son's coat.

Hyperbole was created on the basis of the element of height of the word "son" in this text. Hyperbole is inflamed by words "height" and "star" in first speaker and words "coat" and "lower part" by the second speaker. So, hyperbole in the speech of the second speaker caused laughter.

Hyperbole is one of stylistic devices which have great importance in English humorous texts. Hyperbole is used to show critical estimate in the following humorous text:

Once Margaret Thatcher died, and a few days later the Devil dragged her by the hair to the pearly gates. God asked him:

- "What do you think you're doing? I don't want her".

- "Oh come on, do me a favour," replied the Devil, "I've only had her three days and she's already closed down four furnaces!"

The English showed their attitude to politician former prime minister Margaret Thatcher who closed furnaces although she was sent to Hades, so the Devil make a request to God remove her to his place as a humour. Margaret Thatcher makes problem for the Devil, this is hyperbole. Here hyperbole was created on the basis of the words "Hades", "fire", "close", "the Devil". In real, anybody cannot close down Hades furnaces.

Pay attention to the next English humorous in which hyperbole is used:
A woman needed to buy her mother a birthday present. She didn't know what to buy her mother. She only had one day to buy her mother something. So she went out window shopping. Soon enough, she walked by a pet store window. She thought to herself, "What a lovely idea for a present! My mother is so lonely and she needs a pet."

The woman went into the store and saw many wonderful animals. Puppy dogs, fluffy cats, gold fish, cute mice. But the woman didn't think these were special enough. She asked the manager if he had a pet that was really special.

The manager thought for a moment and replied, "Yes, but it costs a lot of money. \$5,000" "I have a parrot that can speak 7 languages, Chinese, English, French, Korean, German, Russian and even Hindi!"

The woman said, "Perfect" and bought the bird. She sent it by special delivery to her mother, so she would get it the next day.

The next evening after work, the woman called her mother. She asked, "How do you like your birthday present."

Her mother replied, "Thank you, IT'S DELICIOUS!"

Laughter caused on the basis of "a parrot which can speak" in this humorous text. Hyperbole is used in this text. Hyperbole is created by the phrase "have a parrot that can speak 7 languages, Chinese, English, French, Korean, German, Russian and even Hindi!". Describing the parrot so intelligent means that hyperbole is used in the text. Describing the parrot so intelligent, the price of it is $5000 \$$ and woman's mother cooked and ate this 
parrot not informing this cause laughter for reader and listener of this text.

As a conclusion, I can say that stylistic devices metaphor, metonymy, hyperbole are used active in Uzbek and English folklore, though, these nations' humorous texts. The role of every stylistic device is greater in creating humor. According to investigation this paper not above mentioned stylistic devices but others, such as pun, irony, oxymoron, personification, and allusion are used active in humorous texts.

Speaker's speech expresses negative emotional attitude to the object in humorous texts created with metaphor. Speech implicit meaning of metaphors is basis of laugh and it is formed in style of witting with specific pun.

Laugh is caused by metonymy on the basis of mutual relation between speaker and listener in the process of speech.

In particular, presupposition on the basis of hyperbole causes laugh in humorous texts.

We should pay attention to these peculiarities of stylistic devices when we investigate humor and humorous texts from the aspect of linguistics, folklore, translation of humor and others.

\section{Bibliography}

1. Chiaro, D. (1992). The language of jokes: Analysing verbal play. London: Routledge.

2. Crystal D. (1999) "The Future of the Englishes". English Today 15(2), 10-20.

3. Galperin I., 1981, Stylistics. Moscow.

4. Galperin I. R. Stylistics. Moscow. "High school”. 1977.
5. Nash W., 1985, The Language and Humour. Style and Technique in Comic Discourse.

6. Norrik Neal R. 1993. Conversational Joking: Humor in Everyday Talk. Bloomington \& Indianapolis: Indiana University Press.

7. Абдурахмонов Ш. А. Ўзбек бадиий нутқида кулги қўзғатувчи лисоний воситалар. Номзодлик диссератцияси, 1997.

8. Абрамович Г. Л. Введение в литературоведени. М., 1953.

9. Арнольд И. В. Стилистика современного английского языка. - Л. : Просвещение, 1981. - 340 с.

10. Аския. Тошкент, 1970.

11. Бобохонова Л. Т. Инглиз тили стилистикаси. - Тошкент : Ўқитувчи, 1995.

12. Виноградов В. В. Основные типы лексического значения слова. Избранные труды. Лексикография и лексикология. - М. : Наука. 1977. - 312 с.

13. Хожиев А. Лингвистик терминларнинг изохли луғати. - Тошкент, 1985.

14. Хожиев А. Тилшунослик терминлари луғати, "Ўзбекистон миллий энциклопедияси" Давлат илмий нашриёти. - Тошкент, 2002.

\section{Bibliography}

1. Chiaro, D. (1992). The language of jokes: Analysing verbal play. London: Routledge.

2. Crystal D. (1999) "The Future of the Englishes". English Today 15(2), 10-20.

3. Galperin I., 1981, Stylistics. Moscow.

4. Galperin I.R. Stylistics. Moscow. "High school". 1977.

5. Nash W., 1985, The Language and Humour. Style and Technique in Comic Discourse.

6. Norrik Neal R. 1993. Conversational Joking: Humor in Everyday Talk. Bloomington \& Indianapolis: Indiana University Press. 
7. Abdurahmonov Sh. A. Uzbek badiij nutqida kulgi quzg'atuvchi lisonij vositalar. Nomzodlik disseratcijasi, 1997.

8. Abramovich G. L. Vvedenie v literaturovedeni. M., 1953.

9. Arnol'd I. V. Stilistika sovremennogo anglijskogo jazyka. - L. : Prosveshhenie, 1981. - $340 \mathrm{~s}$.

10. Askija. Toshkent, 1970.

11. Bobohonova L. T. Ingliz tili stilistikasi. Toshkent : Uqituvchi, 1995.
12. Vinogradov V. V. Osnovnye tipy leksicheskogo znachenija slova. Izbrannye trudy. Leksikografija i leksikologija. M. : Nauka. 1977. - 312 s.

13. Hozhiev A. Lingvistik terminlarning izohli lug'ati. - Toshkent, 1985.

14. Hozhiev A. Tilshunoslik terminlari lug'ati, "Uzbekiston millij enciklopedijasi" Davlat ilmij nashrijoti. Toshkent, 2002.

(C) Yuldoshev U. R., 2017. 